ALPHA N 27 Diciembre 2008 (107-122)

ISSN 0716-4254

http://alpha.ulagos.cl

\title{
SELF PORTRAIT WITH WIFE AND MODELS: UN ANÁLISIS SEMIÓTICO
}

Self Portrait with wife and models: A Semiotic analysis

\author{
Jenny G. Farías de Estany* \\ María Inés Mendoza Bernal**
}

Resumen

El siguiente artículo presenta el análisis semiótico de Self Portrait with wife and models, Paris, 1981, autorretrato realizado por el fotógrafo alemán Helmut Newton incluido con el $\mathrm{N}^{\circ} 17$ en Private Property, su portafolio antológico. Esta toma fotográfica es abordada fundamentalmente desde la perspectiva triádica de Peirce (1986) en diálogo teórico con los niveles de la imagen de Barthes (1986) y la metodología iconológica de Panofsky (1970). Los resultados de la investigación muestran el carácter erótico de la fotografía de Newton que constituye su legisigno, la presencia de historias múltiples y relaciones intertextuales que manifiestan un compendio de la historia personal del autor y la puesta en escena del cuerpo femenino como elemento contradictorio a los códigos estéticos tradicionales de la industria de la moda.

Palabras clave: Análisis semiótico, fotografía erótica, legisigno, autorretrato.

\section{Abstract}

The following article presents the Semiotic Analysis of Self Portrait with wife and models, Paris, 1981, by the german photographer Helmut Newton (Photograph $\mathrm{N}^{\circ}$ 17), which is included in his memorable briefcase named Private Property. These photograph is undertaken fundamentally from Peirce's perspective (1986) in theoretical dialogue with the levels of the image of Barthes (1986), and Panofsky's iconologic methodology (1970). The results of the investigation shows the erotic character of Newton's photography that constitutes its legisign, the presence of multiple histories and intertextual relations that declare a summary of the personal history of the author and staging of the female body as a contradictory element to the traditional esthetic codes of the fashion industry.

Key words: Semiotic analysis, erotic photography, legisingn, self-portrait.

\section{INTRODUCCIÓN}

La importancia de abordar el análisis de las imágenes fotográficas se centra en la necesidad que existe, como espectadores-interpretantes, de comprender el entorno visual o semioesfera generada por la industria cultural. 
Esto significa que, así como se desmontan los textos verbales para llegar a la intención de comunicación del emisor, se requiere entender las imágenes como textos visuales dentro del proceso comunicacional y contextualizarlas como discurso visual.

Estas reflexiones semióticas giran en torno a las imágenes de Helmut Newton, fotógrafo de origen alemán, mayormente conocido por sus fotos de moda y de desnudos femeninos, publicados en las revistas Vogue, Marie Claire, Elle, Línea Italiana, etc. Las fotografías a las que nos referiremos se encuentran recogidas en Private Property (Propiedad Privada) (Schirmer's Visual Library, 1990), una antología de 45 imágenes en blanco y negro elaboradas entre 1972 y 1983 de las cuales elegiremos, para este análisis, la fotografía No 17 titulada "Self Portrait with wife and models. París 1981" que reproducimos a continuación. Esta recopilación posee retratos de personajes conocidos e imágenes eróticas desarrolladas en diferentes locaciones geográficas y sobre escenarios que presentan los estilos de vida de los fotografiados.

Este "autorretrato con esposa y modelo", elaborada en los estudios de Vogue, es una imagen fotográfica en blanco y negro en formato cuadrado, donde Newton recoge su propia imagen, la de su esposa Alice Springs ${ }^{1}$ y las de dos modelos desnudas en una sesión fotográfica. Siendo nuestro objetivo el análisis semiótico del autorretrato en referencia, se abordará teórica y metodológicamente desde las categorías tricotómicas de Peirce (1986), los niveles de la imagen de Barthes (1986) y la metodología de Panofsky (1970).

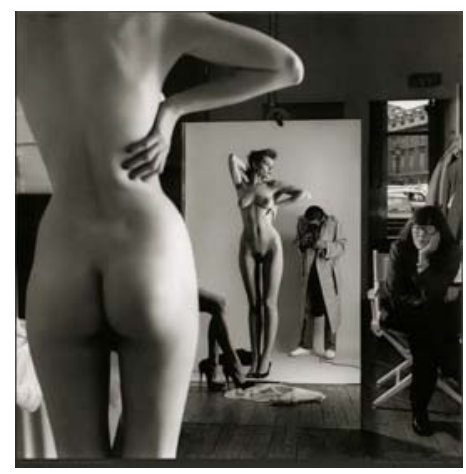

${ }^{1}$ Nombre de nacimiento es June Brown, actriz nacida en Australia y modelo de Helmut Newton. Aprendió a hacer fotografía con él, con quien estuvo casada por más de 50 años. La editorial Taschen publicó su vida y obra en una antología denominada Mrs. Newton. Ver enlace: http://www.taschen.com/pages/en/catalogue/books/photography/all/facts/01354.htm 
Self portrait with wife and models

\section{FUNDAMENTACIÓN TEÓRICO-METODOLÓGICA}

2.1. La trinidad semiótica. Charles Sanders Peirce, lógico, filósofo y epistemólogo, planteó una teoría del estudio de los signos que desarrolla diversas categorías sobre la semiosis a partir de un proceso triádico de inferencia. Los tres primeros elementos que describe dentro de esa clasificación sígnica (representamen, objeto e interpretante) los explica a través de la definición del signo

Un signo o representamen, es algo que, para alguien, representa o se refiere a algo en algún aspecto o carácter. Se dirige a alguien, esto es, crea en la mente de esa persona un signo equivalente, o, tal vez, un signo más desarrollado. Este signo creado es lo que yo llamo el interpretante del primer signo. El signo está en lugar de algo, su objeto. Está en lugar de ese objeto, no en todos los aspectos, sino sólo con referencia a una suerte de idea, que a veces he llamado el fundamento del representamen (1986:22).

De esto se deriva que cada representamen se conecta con tres entidades que son el fundamento - traducido también como "base" o como "ground"el objeto y el interpretante. (Colleted Papers 2.228, en Merrel, 1998:44). El punto a destacar de estas tres entidades no está en sus definiciones como tal, sino en las relaciones que se establecen entre ellas a partir del signo.

Para que estemos en presencia de un signo, éste debe cumplir con tres condiciones implícitas en la definición peirciana: en primer lugar, debe tener cualidades que sirvan para distinguirlo (una palabra o sonido particular que lo diferencie de otro); en segundo lugar, debe tener un objeto (condición necesaria pero no suficiente) y, en tercer lugar, la relación debe ser triádica "comportar un representamen que debe ser reconocido como el signo de un objeto a través de un interpretante” (Vitale, 2002:12).

Ahora bien, el interpretante viene a constituirse como otro signo, como cualquier signo que interpreta a otro signo y que posee múltiples posibilidades de expresión

un signo de otro sistema semiótico diferente al representamen (palabra/dibujo), un deíctico que apunta al objeto (palabra/dedo índice), una definición en el mismo sistema semiótico (palabra/concepto), la traducción de un término en otra lengua (español/inglés), uso de términos sinónimos en la misma lengua (palabra/sinónimo) o la asociación emotiva que provoca el representamen (palabra/valor/ emoción) (Vitale, 2002:13). 
Los interpretantes generan lo que se conoce como semiosis ilimitada, pues cada interpretante se constituye en otro representamen que genera nuevamente la relación tricotómica. El interpretante que ya ha transcurrido por esa tercera condición de ser signo — antes descrita — se clasifica, a su vez, en interpretante inmediato, dinámico y final. El interpretante inmediato según apunta Peirce "es una abstracción: consiste en una posibilidad" (Peirce, 1986:109). Es todo signo que se halla fuera de su contexto y de las circunstancias de su manifestación. Es la relación de ese signo con su objeto independientemente de la situación de comunicación.

Por su parte, el interpretante dinámico consiste "en el efecto directo realmente producido por un signo en su intérprete (...) Mi interpretante Dinámico es aquel que es experimentado en cada acto de interpretación, y en cada uno de éstos es diferente de cualquier otro (...) El interpretante Dinámico es un evento singular y real” (Peirce, 1986:109). De esta forma, este interpretante provoca un efecto singular en un intérprete frente a una situación concreta de manifestación del signo.

El tercer y último interpretante explicado por Peirce es el interpretante final o normal y presupone los interpretantes inmediato y dinámico. A este respecto, el interpretante final es pensado como un hábito que hace posible la interpretación recurrente y estable de un signo (Deladalle, 1996:103).

Ahora bien, el objeto (progenitor del signo) es lo que representa ese signo y Peirce lo conceptualiza de la siguiente forma

Estar en lugar de otro, es decir, estar en tal relación con otro que, para ciertos propósitos, sea tratado por ciertas mentes como si se fuera ese otro. Consecuentemente, un vocero, un diputado, un apoderado, un agente (...) todos representan alguna otra cosa, de diversas maneras, para mentes que así lo consideran (1986:43).

Peirce también distingue en el objeto dos variantes: el objeto inmediato y el dinámico. El objeto inmediato es definido como "el objeto tal como es representado en el contexto de un proceso de semiosis", diferenciado del objeto dinámico como "el objeto sin considerar ningún aspecto particular suyo, el objeto en tal relación como un estudio ilimitado y final lo mostraría" (Peirce, Collected Papers, 8.133, en Andacht, 2006:7).

Finalmente, la base vendría siendo el contexto que ofrece las posibilidades de la significación en un punto espacio-temporal (Merrel, 1998:45). El fundamento o base "es uno o varios rasgos o atributos de un objeto que permiten identificarlo, es decir, los rasgos distintivos que lo diferencian de otros objetos” (Vitale, 2002:23), lo cual esquematizó Peirce, en su momento, y que hemos re-elaborado de la manera siguiente: 


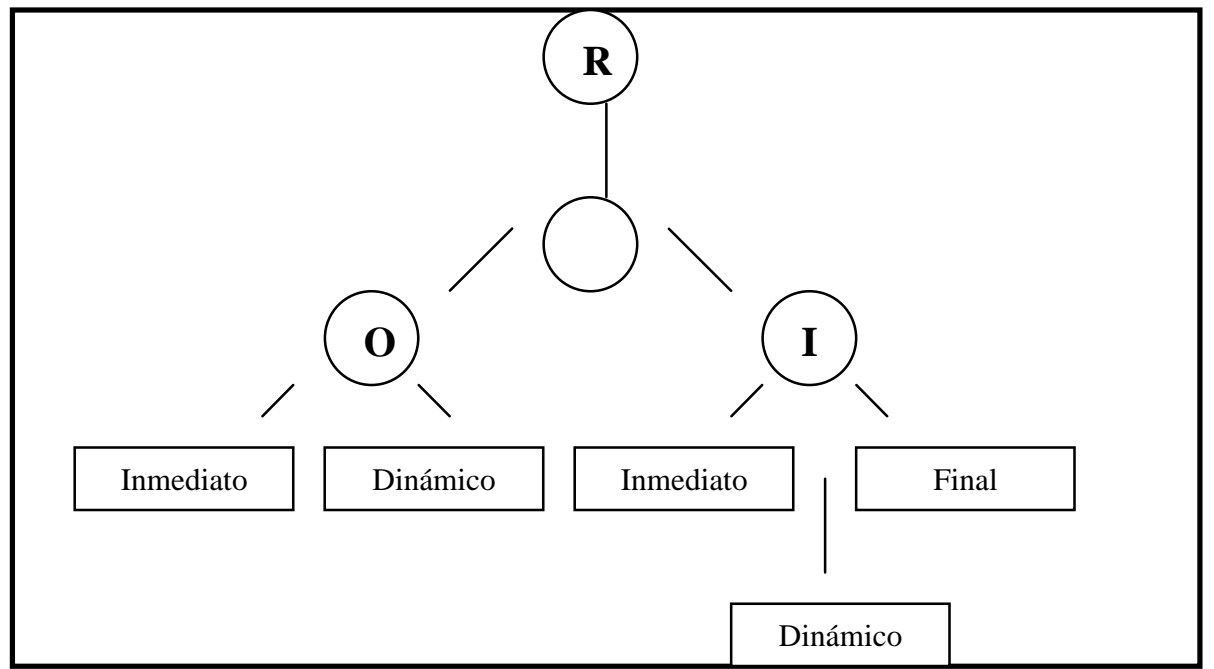

La relación triádica de los elementos del signo se suceden en relación con las categorías de Primeridad, Segundidad y Terceridad, a las que Peirce define como tendencias hacia las cuales se dirigen los pensamientos (Colleted Papers 1.356, en Merrel, 1998:52). La Primeridad está referida a una cualidad, sensación; es el modo de significación de lo que es tal como es, sin referencia a otra cosa. Es la posibilidad que, en algún momento futuro, quizás pueda cobrarse de una clasificación determinada de manera que entre en relación semiótica con otras entidades. "La existencia dentro de la Primeridad sería, si se puede imaginarla, como la de un sonámbulo, un autómata” (Merrel, 1998:53).

La Segundidad es el modo de significación de lo que es tal y como es, con respecto a algo más, pero sin referencia a un tercero e incluye la conciencia de algún otro. La Terceridad abarca la mediación, la síntesis de las dos categorías anteriores (Collected Papers, 8.328)

La Segundidad, se trata precisamente de algo actualizado a la manera de esta entidad en este momento. Es un aquí y un ahora: una singularidad, una particularidad (...) es la otredad en el sentido más primitivo de la palabra” (Merrel, 1998:55).

De esta forma, los tres elementos que constituyen la semiosis se tricotomizan sobre las categorías faneroscópicas ${ }^{2}$ y dan origen a nueve tipos

${ }^{2}$ Faneron significa la apariencia en los sentidos del signo. "Propongo utilizar la palabra faneron como un nombre propio para denotar el contenido total de una conciencia (...) la suma de todo lo que tenemos en la mente, de cualquier manera que sea, sin mirar su valor cognitivo. Esto es bastante vago: pero es voluntario, sólo subrayaré que no limito la referencia a un estado 
de clasificación sígnica peirceana como se observa en el siguiente cuadro que reproduce Andach (2006).

\begin{tabular}{|c|l|l|l|}
\hline FANERON/SEMIOSIS & PRIMERIDAD & SEGUNDIDAD & TERCERIDAD \\
\hline $\mathrm{R}$ & CUALISIGNO & SINSIGNO & LEGISIGNO \\
\hline $\mathrm{O}$ & ÍCONO & ÍNDICE & SÍMBOLO \\
\hline $\mathrm{I}$ & REMA & DECISIGNO & ARGUMENTO \\
\hline
\end{tabular}

En este sentido, el representamen se divide en cualisigno, sinsigno y legisigno. El cualisigno es de la categoría de la primeridad y representa una cualidad (color, textura, forma) que es, en sí misma, una posibilidad hasta que un sinsigno (un signo existente) se manifieste. El sinsigno corresponde a la categoría de la segundidad porque es "cualquier cosa existente que es un signo. El sinsigno es una materialización del cualisigno y cobra significado gracias a un legisigno (un tipo general del que es la manifestación)” (Vitale, 2002:29-30). El tercer estadio o legisigno lo define Peirce como

una ley que es un signo. Esta ley es generalmente establecida por los hombres. Todo signo convencional es un legisigno (pero no recíprocamente). No es un objeto único sino un tipo general que, como se ha acordado, será significante. Cada legisigno significa por medio de una instancia de su aplicación, que puede ser llamada una Réplica de él. Así, la palabra "el" (artículo) puede aparecer de quince a veinticuatro veces en una página. En todas esas ocurrencias es única y misma palabra, el mismo legisigno. Cada una de esas instancias es una Réplica. La Réplica es un sinsigno. En consecuencia, todo legisigno requiere sinsignos (...) Tampoco la Réplica sería significante, si no fuera por la ley que la convierte en tal (1986:29-30).

Por último, las tres categorías faneroscópicas aplicadas al objeto generan tres tipos de signos denominados íconos, índices y símbolos. Según Peirce, el primero está referido al signo que establece una relación de analogía con su objeto (1986:46). El segundo es un signo que entabla con el objeto una relación existencial (1986:30) y el tercero es un representamen que se refiere a su objeto dinámico por convención, hábito o ley (1986:57).

2.2. Los niveles de la imagen: Barthes y Panofsky. En La Cámara Lúcida -Notas sobre la fotografía - Barthes (1982) alude al concepto de fotografía

de conciencia instantáneo; puesto que la cláusula "de cualquier manera que sea" abarca la memoria y toda cognición habitual.” Manuscrito 908, Peirce en: http://robert.marty. perso. cegetel .net/semiotique/preg41.htm. "Lo que yo llamo "faneroscopía" (...) es la descripción de lo que está frente a la mente o en la conciencia, tal como aparece” (Peirce, Collected Papers 8.203, en Deladalle, 1996:59). 
"unaria" al referirse a aquel tipo de imagen altamente difundida (ej. Fotoreportajes) que no provoca en el perceptor (Spectator, al estilo barthesiano) ningún interés especial, no lo atrae notoriamente; imágenes que se hojean pero no se rememoran (85). Asimismo, Barthes habla del "punctum" como ese elemento ausente en la fotografía unaria que punza, que atrae la mirada inevitablemente (87), lo que vendría a ser el signo indicial en términos peirceanos (Collected Papers 4.447, citado en Andach, 2006:21) y el indexappeal o llamamiento indicial como lo denomina Andacht (2002:74).

Las fotografías pornográficas pertenecen al tipo de foto unaria, pues expresan su homogeneidad al mostrar explícitamente una sola cosa: el sexo; vale decir, un Studium (campo de interés cultural, del gusto inconsecuente de una fotografía) sin punctum (Barthes, 1982:85).

Barthes menciona los dos niveles de la imagen — de manera más metodológica que estrictamente secuencial- como la denotación y la connotación. El primero explica ese “estado adánico de la imagen”, el nivel literal, la imagen identificada mediante sus elementos, "despojada utópicamente de sus connotaciones, la imagen se volvería radicalmente objetiva, es decir, en resumidas cuentas, inocente" (Barthes, 1986:39). El segundo es "en cierta manera, el modo en que la sociedad ofrece al lector su opinión sobre aquél” (Barthes, 1986:13).

Este segundo sentido que Barthes atribuye a la imagen fotográfica, se elabora en el transcurso de diferentes niveles de producción de la fotografía tales como el trucaje, la pose, los objetos, la fotogenia, el esteticismo y la sintaxis. La pose y los objetos (elementos) que el fotógrafo dispone en el formato fotográfico son "inductores habituales de asociaciones de ideas (...), auténticos símbolos"; la fotogenia es la imagen sublimada a partir de la técnica fotográfica (la iluminación, el movimiento sugerido, la toma en blanco y negro, etc.); el esteticismo busca convertir la fotografía en pintura a través de la composición o la imitación de la técnica pictórica y la sintaxis plantea la lectura discursiva de objetos-signos dentro de una misma fotografía o en una serie (Barthes, 1986:16).

Panofsky, en sus estudios sobre la iconología, plantea una metodología para abordar estos signos que se fundamenta en tres niveles secuenciales equiparables a los niveles de Barthes: la descripción preiconográfica (nivel denotativo barthesiano), el análisis iconográfico y la interpretación iconológica (niveles de la connotación barthesiana). La descripción preiconográfica está determinada por la identificación de lo que perciben los sentidos, por esa significación primaria o natural relacionada con el mundo fáctico, "con determinados objetos que conozco por experiencia práctica y mediante la identificación del cambio en sus relaciones con determinados actos o acontecimientos” (Panofsky, 1970:37). 
Jenny Farías - María Inés Mendoza

En el segundo nivel o análisis iconográfico, la imagen pasa a ser clasificada e interpretada dentro de una cultura específica

En este nivel utilizamos nuestros conocimientos y nuestro pensamiento asociativo para comprender lo que nuestros sentidos han captado, accedemos así al significado convencional de las cosas; esto es, al significado por todos conocido y aceptado como válido. Esto implica tener un conocimiento amplio de la cultura en la cual se origina el fenómeno o situación que queremos entender (Gómez, 2003:9).

Finalmente, el nivel de la interpretación iconológica busca descubrir e interpretar los "valores simbólicos"; hallar los significados ocultos que se encuentran en el inconsciente individual o colectivo. Es el nivel de la significación intrínseca o de contenido

El significado intrínseco o contenido se lo aprehende reconociendo aquellos principios subyacentes que revelan la actitud básica de una nación, de un período, una clase, una convicción religiosa o filosófica, todo esto modificado por una personalidad o condensado en una obra (Panofsky, 1970:41).

\section{ANÁLISIS Y RESULTADOS}

3.1. Los niveles metodológicos de análisis. Los íconos de la imagen denotada se podrían describir en tres tiempos o en tres cuadrantes verticales que recorren la mirada del espectador de izquierda a derecha. El primer tiempo describe un torso femenino, de espaldas, desnudo de los hombros hacia las rodillas sobre el que se posa la mano derecha de la mujer a la altura de su cintura. El segundo tiempo se inicia con el brazo y antebrazo que completa la imagen femenina del primer tiempo, y continúa en la imagen que describe el espejo colocado sobre un piso de madera, frente al cuerpo femenino del primer cuadrante. Esta imagen especular describe — del lado izquierdo — unas piernas femeninas desnudas sobre zapatos oscuros altos, el plano general de frente de la mujer del primer cuadrante sobre zapatos oscuros altos, blanca, joven, de pelo rizado, delgada, mirando hacia su derecha sobre su hombro y con el brazo izquierdo elevado hacia su espalda. Detrás de ella (es decir, hacia el espectador) se encuentra un ropaje oscuro arrojado en el suelo y delante de ella (es decir, hacia la imagen) un ropaje claro arrojado en el suelo; en el lado derecho - en el espejo- - hay un hombre vestido con sobretodo largo y zapatos deportivos blancos, inclinado hacia la cámara fotográfica que sostiene entre sus manos. El tercer cuadrante muestra a una mujer adulta sentada sobre una silla blanca, de cabello negro liso, con grandes anteojos, apoyando su rostro sobre su codo izquierdo y observando la escena. Detrás de esta mujer 
adulta se encuentra una puerta abierta, cuyo letrero superior dice "sortie" y por donde se pueden observar carros y edificios de la ciudad. El resultado de nuestra división en tres cuadrantes verticales es el siguiente
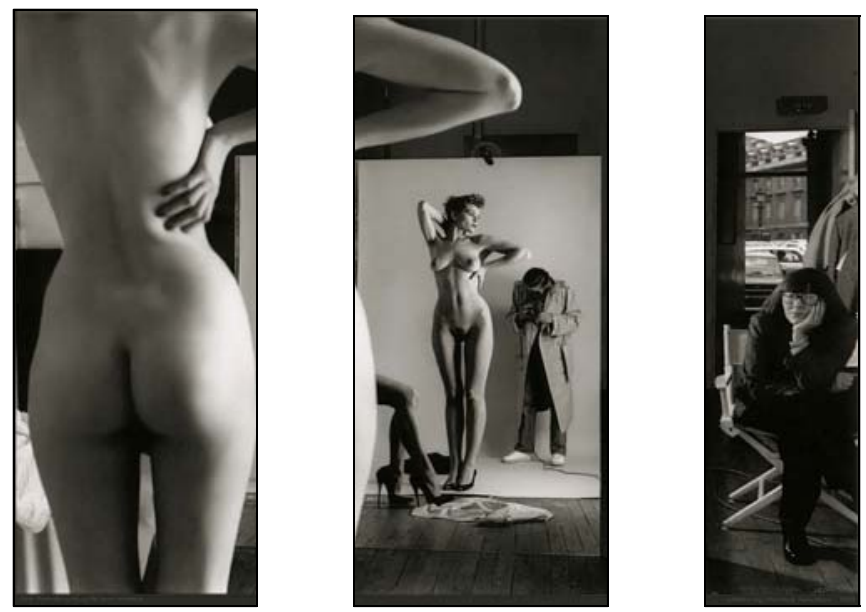

Para analizar la imagen a partir del segundo nivel barthesiano partimos del título - Autorretrato con esposa y modelos, París, 1981- que ancla el significado. De allí que la escena nos muestra a Newton en una sesión fotográfica con dos modelos frente a la mirada de su esposa June. Los elementos dentro de la escena descritos en el nivel denotativo ahora se relacionan con el significado de la fotografía a través de varios aspectos: 1) la desnudez como representación de la sensualidad, lo erótico, la sexualidad; 2) los zapatos altos con relación a la elegancia, el fetichismo; 3) los ropajes arrojados al suelo dan cuenta de la informalidad de la toma al igual que los cables que se visualizan; 4) la mujer joven y blanca; 5) el fotógrafo irreverente, famoso, de experiencia, que por ser tan conocido se autorretrata deseando que el espectador lo recuerde por su profesión más que por sus rasgos físicos; 6) June, es la esposa mostrada como una espectadora particular, intelectual que evalúa el trabajo que Newton realiza; 7) la puerta abierta y la palabra "Sortie" ("salida” en francés) ofrece el ambiente del estudio parisino existente en una urbe privilegiada, de fascinante movimiento intelectual y cultural que se deja ver en la imagen y hace de respaldo visual a una June esposa, modelo, actriz y fotógrafa.

La imagen también plantea una intertextualidad cuando es asociada con otro texto cualquiera, "un texto cultural, ya sea real o virtual, escrito o icónico, contingente o imaginario” (Zavala, 2003:55). En este caso podría darse una réplica entre la fotografía y la pintura de Las Meninas de Velásquez —que reproducimos a continuación: http://www.ibiblio.org/— tal como lo 
relaciona Blonsky cuando equipara los personajes de la obra pictórica con los del autorretrato de Newton y expresa que "where his wife could be the king, he, the painter and the nude, a princess" ("la esposa podría ser el rey; él, el pintor y las modelos desnudas, las princesas”. Blonsky, en Newton, 1990:13).

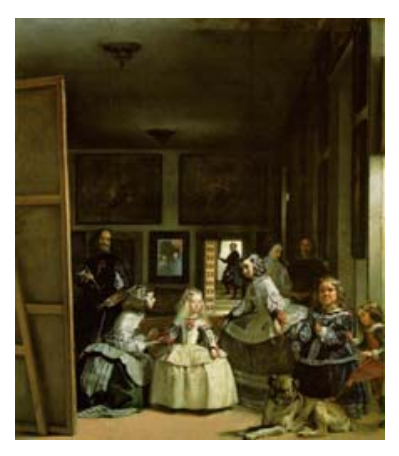

Esta intertextualidad también se observa en el nivel connotativo del esteticismo que utiliza elementos de la técnica pictórica en la toma fotográfica. En este caso, se refiere a la composición clásica de la perspectiva geométrica que la fotografía vino a imponer con mayor credibilidad que la pintura.

Los otros niveles de producción de la toma fotográfica se complementan con los elementos de la composición (Modelos, Newton y June) y las poses que estos mantienen. Las piernas desnudas exhibidas de la modelo oculta, el cuerpo sin desparpajos de la modelo central, la observación atenta de June sobre la modelo central y la acción de Newton sobre la cámara. Cada personaje presente en la toma relata, a través de sus gestos, la acción que acomete.

Asimismo, la fotogenia de la imagen está representada por el uso de la imagen en blanco y negro que la aleja de la realidad, la sublimiza y traduce los colores de la escena real en la nueva escena fotográfica.

Finalmente, la sintaxis como último nivel de producción connotativo se plantea con relación a la historia que de la imagen se deriva y su vinculación con las 44 fotografías restantes del portafolio - al cual remitimos- cargadas de erotismo, sexo, fetichismo y las variantes posibles.

Bajo la metodología de Panofsky, las imágenes que pertenecen a este portafolio y el autorretrato objeto de estudio deben ser analizadas desde un infrasaber icónico. A partir de esta antología de Helmut Newton y el conocimiento que se tiene se complementa el análisis. Newton estuvo involucrado profesionalmente con la fotografía de moda (modelos profesionales) y de espectáculo (personalidades del mundo musical, actrices, artistas plásticos). Así pues, dominaba los códigos de esa industria cultural y 
en múltiples ocasiones los transgredía. Le atribuía al desnudo femenino, por ejemplo, un carácter distintivo. La mujer era representada en diversas facetas y no sólo como objeto estético. Colocaba a las mujeres en acción frente a la cámara fotográfica, desnudaba sus cuerpos, sus pasiones y pensamientos. Las imágenes de Newton proporcionan datos sobre estilos de vida, formas de vestir de cierta época, tiempos y espacios. El autorretrato muestra una escena parisina de los años ochenta, en época otoño-invierno, entre la desnudez (presente en su obra a través de la modelo) y la reflexión fotográfica (irreverencia de su obra a través de la presencia de su esposa en la escena).

3.2. El autorretrato y el espejo. Con respecto al retrato (o autorretrato), Barthes dice: "Cuando me siento observado por el objetivo todo cambia. Me constituyo en el acto de posar, me fabrico instantáneamente otro cuerpo, me transformo por adelantado en imagen” (1982:41). Ese actuar es lo que se denomina el "self enactment", estudiado por Andacht (2002), que trasforma la escena de lo cotidiano no visto a lo que se convertirá en imagen; lo privado en público. En la fotografía $\mathrm{N}^{\circ} 17$, la pose de Newton exhibe cómo desea este fotógrafo que lo recuerden; más que su rostro (que no se muestra) se inmortaliza su actitud, su acción, su oficio. Es una actitud narcisista en el discurso visual del autorretrato. El rol que cumple el espejo en el autorretrato no sólo permite reflejarse a sí mismo (retratarse), sino ver el cuerpo de la modelo en una doble perspectiva: de espaldas y de frente, visión imposible con la mirada común. Por lo demás la relación de la fotografía con el teatro también alude a la pose, a "el actuar". Newton, como buen director de arte, ordena visualmente la escena teatral a fotografiar (el autorretrato), cuyos personajes (June y modelos) pertenecen al elenco.

3.3. De lo pornográfico a lo erótico. Entre los griegos, Eros era el dios del amor, la lujuria y el sexo. La imagen de Helmut Newton conjuga este mito. La sensualidad, el amor y las referencias del cuerpo desnudo son atrapados en la superficie fotográfica que las coloca en el plano de la imagen que fue.

En el caso de las imágenes de Newton, éstas pasan de lo pornográfico a lo erótico, entendiendo lo erótico como la fotografía pornográfica alterada, trasformada, donde existen elementos secundarios que distraen la mirada, ocultan a medias, se centran en narraciones varias, emplean sombras sugerentes, desenfoques, etc.

La fotografía pornográfica hace del sexo un fetiche, un objeto inmóvil, mientras que la fotografía erótica no hace de él su objeto central, incluso, lleva al espectador fuera del marco manifestando el punctum más allá del campo, lanzando el deseo. En este caso, el punctum también está relacionado con el tiempo, es decir, sobre lo que la fotografía me dice que sucederá a posteriori. Newton deja abiertas esas historias para que el Spectator las 
complete. En la fotografía que analizamos se presenta un escenario donde existen elementos diferentes al cuerpo desnudo de la modelo que atraen la mirada del espectador, haciendo de ella — la foto- un compendio de múltiples historias simultáneas (Helmut, June, las modelos) que se solapan para crear narraciones varias.

En la imagen se pueden distinguir otros punctum: la mirada atenta de June como si fuera la editora (evaluadora, intelectual) de modas y un Newton sobre la cámara que deja ver la cotidianidad de su trabajo, lo que se encuentra oculto tras las imágenes que él realiza para revistas de moda y que generalmente no es puesto en evidencia; el binomio desnudo/vestido de las modelos en contraposición con los ropajes equipados de June y Newton. Estos énfasis impulsan la historia que a posteriori cada perceptor puede crear.

Marshall Blonsky, semiólogo, crítico de arte y docente, expresa —en la introducción a Private Property - que Newton juega con la imaginación, pues el espectador es dejado con el deseo para que continúe la narración, para que complete la escena (1990:9).

En términos barthesianos, la fotografía es subversiva y no cuando asusta, trastorna o incluso estigmatiza, sino cuando es pensativa (1982:81) y ésta es, precisamente, la posibilidad que el autor-creador de la imagen provoca.

3.4. Los interpretantes, la terceridad, el legisigno. El autorretrato de Helmut Newton constituiría, desde la óptica de Peirce, un representamen que se verifica en la fotografía misma publicada en la serie antológica. Su objeto se refiere a todas las figuras distinguibles en la imagen fotográfica y su interpretante es la relación de estos dos elementos anteriores que es, precisamente, lo que se ha venido analizando para ir construyendo el legisigno de su obra.

En este sentido, el objeto dinámico (exterior a la semiosis) en la fotografía de Helmut Newton son las múltiples posibilidades de tomas que pudo haber hecho de la situación fotografiable y, con ellas, las diversas posibilidades de interpretación; mientras que el objeto inmediato (interior a la semiosis) es la opción escogida para la toma fotográfica, el modo como Newton representó los elementos de la imagen y que, a largo plazo, puede llegar a convertirse en un interpretante final. De todas las formas de representación de la desnudez femenina (objeto dinámico), Newton plasmó la pose desinhibida, de espaldas de la modelo (objeto inmediato) como aquel que describe principalmente al acto fotográfico como huella luminosa, pues se conecta físicamente con su referente. Sin embargo, no excluye al signo icónico (analogía) ni al futuro signo simbólico, pues la fotografía sigue el orden de la semejanza y de la convención (Dubois, 1986:60). De allí que las imágenes de Newton vuelven al referente por esa huella que han dejado sobre 
el soporte fotográfico pero, a su vez, poseen las características de esos referentes (íconos) que nos hacen distinguir quién es Newton, June o las modelos; cómo son sus características físicas, cómo visten o cómo desvisten sus cuerpos, etc.

En este signo indicial de la fotografía se presentan los principios de singularidad, atestiguamiento y designación. La singularidad se remite a esa marca indicial única; a la unicidad misma del referente. Newton no podrá repetir jamás con exactitud las tomas realizadas; incluso, colocando los objetos de igual forma, utilizando las mismas modelos o misma cámara. Ese tiempo y espacio es único al hacer el click.

Peirce llamaba a estos elementos unidades singulares, colecciones singulares de unidades y continuos singulares (Collected Papers 2.274, en Peirce, 2005:10) mientras que Barthes lo revelaba como el particular absoluto (1982:31).

El principio de atestiguamiento evidencia lo sucedido. Es el testimonio y ratificación de la existencia del objeto de procedencia. La toma fotográfica del autorretrato verifica que, sin lugar a dudas, Newton se encontraba en ese escenario con esas tres personas y tomando esa fotografía.

Por último, el principio de designación muestra el punctum barthesiano que señala con el dedo hacia algún lugar. En palabras de Peirce (Collected Papers 4.447 citado en Andach, 2006:21), todo lo que llama la atención es un index y - en este caso, el fotográfico — este index es la potencia designadora, vacía de contenido que no afirma nada sólo dice: “Allí” (Dubois, 1986:64). Es el "registro”, el “está ahí” en términos de Barthes (1986:40). En la imagen analizada podemos ver cómo se aplica este principio cuando decimos "Vean esto o aquello”, “Aquí está Helmut”, "Esta es su esposa”, etc.

El index remite a las referencias que todo perceptor va a conseguir en la fotografía. Nos referimos a las marcas halladas en el texto visual y que ofrecen información sobre el soporte, el dispositivo fotográfico, el fotógrafo y el mundo fotografiado. En este sentido, la referencia al soporte se halla en el uso de las emulsiones sensibles, el papel, películas, efectos, etc. (software de la fotografía); la referencia al dispositivo se verifica en el encuadre, numeraciones, y demás elementos que certifican la presencia de la cámara (hardware de la fotografía). La referencia al mundo se verifica por los elementos que se reconocen en la imagen y la referencia al fotógrafo por el estilo que impera en las tomas y por las huellas de la acción misma de fotografiar (sombras, reflejos, etc.) (Farías, 2006:8).

En el caso de la imagen $\mathrm{N}^{\circ} 17$, la referencia al fotógrafo se reconoce no sólo por el estilo de su fotografía ya reconocida, sino por el autorretrato que refleja en el espejo su propio cuerpo.

Finalmente, el cualisigno son las cualidades abstraíbles de la foto, en su condición absoluta. Lo erótico, lo artístico intertextual; lo no pornográfico en 
la imagen de Newton. El sinsigno es la imagen tomada, publicada, expuesta. La imagen en tanto artefacto público y expuesto en un libro a la venta que, en este caso, es el portafolio y el legisigno es la interpretación concreta, contextualizada, la comprensión del mito de Eros encarnado en la imagen específica, el objeto de estudio de la semiótica.

A este respecto, el interpretante final, ubicado en la terceridad dentro de los tres niveles de acercamiento a cualquier experiencia cognoscente, es la tendencia a que algún día resulte de la convergencia completa de los analistas, cuando se acaben las interpretaciones sobre esta obra y se llegue al consenso. En el caso de la fotografía, el estilo corriente o modelo que impone Newton en sus imágenes. Nos referimos a la fotografía erótica de Newton cuyas imágenes juguetean con el cuerpo, la insinuación, el deseo, lo sexual, etc. Este interpretante final coincidiría, en ese momento futuro y muy lejano, con el objeto dinámico en la fotografía de Newton, pues se va revelando como ese interpretante del tercer nivel. De las múltiples posibilidades de expresión del signo (cualidades, primeridad) y, en nuestro caso, de las diversas formas de fotografiar el cuerpo humano, Helmut toma el cuerpo erótico (sinsigno) y lo convierte en lo que sería su legisigno: la fotografía erótica que se convierte en símbolo porque se halla para ser interpretado.

Newton entra en este autorretrato en el mundo de la imagen (mundo de la moda) y se separa, en este instante, del mundo real para ser parte de su propio legisigno.

\section{CONSIDERACIONES FINALES}

El análisis del discurso fotográfico presente en el autorretrato de Newton, desde el punto de vista semiótico, permite inferir que Newton condensa en la obra analizada su historia personal como fotógrafo y como hombre exitoso. En la presencia de las modelos desnudas verifica ser amante de lo erótico, tema fotográfico presente en gran parte de su obra. En su propia presencia se exhibe como hombre amante de su trabajo, que es parte del escenario de la moda, pero, que a la vez, critica dicho mundo a través del estilo que impone en sus imágenes. En la presencia de su esposa se muestra como un hombre afectivo, con una relación madura, de complicidad, de compartir intelectual y profesionalmente.

La imagen aquí analizada presenta uno de los tantos matices que Newton imprime a su obra sobre el desnudo femenino. En este caso, es la desnudez como elemento natural, desprejuiciado del cuerpo. Sin embargo, cuando éste se convierte en objeto fotografiable en las 45 imágenes de Private Property se descubren variaciones tales como la muerte, el fetichismo, el sadomasoquismo, el lesbianismo, el narcisismo, el dolor físico, etc. 
En suma, un análisis más complejo y sistemático de la obra de Newton, en parte, recogida en la antología de la que forma parte la imagen analizada, permitiría, al decir de Peirce, la configuración de su legisigno. Esto debido a la manifestación que a lo largo de su obra fotográfica tendrían sus pensamientos, sentimientos, convicciones, gustos y realidades. La imagen del autorretrato forma parte de la simbología que la fotografía erótica ha impuesto, pero que el lente de Newton ha reinterpretado con singular peculiaridad, por lo que ya forma parte de la cultura visual de nuestro tiempo.

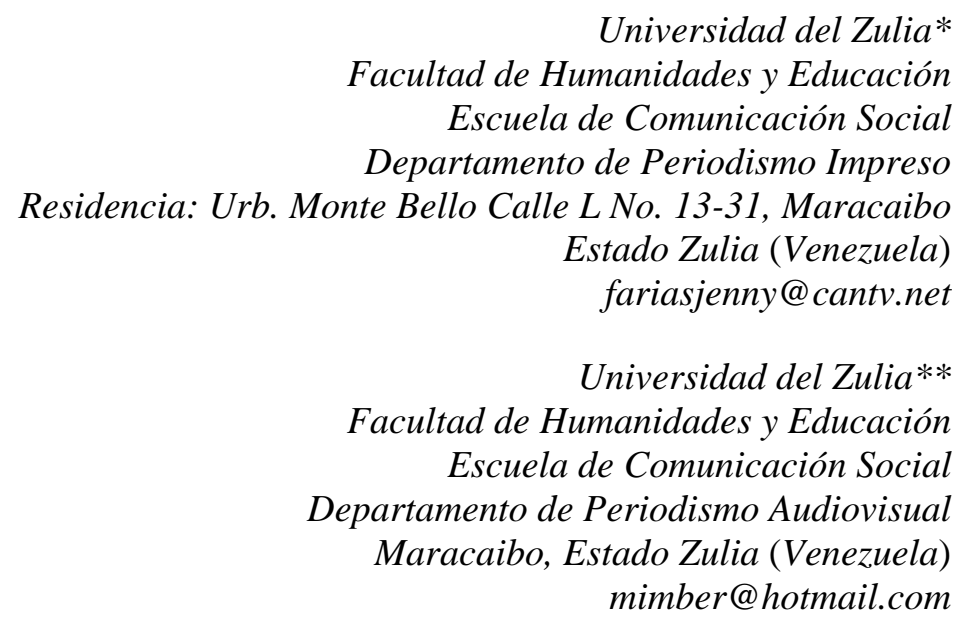

\section{BIBLIOGRAFÍA}

ANDACHT, F. "Signos de identidad, alteridad y cambio: La representación de lo real y de lo imaginario en la cultura contemporánea”. Material de apoyo del Seminario del Doctorado en Ciencias Humanas, Maracaibo: Universidad del Zulia, (26 al 30 de junio) 2006.

------- Big brother te está mirando: la irresistible atracción de un reality show global. Sao Paulo: Ética, Cidadania, e Imprensa, 2002, 63-100.

BARTHES, R. Lo obvio y lo obtuso. Imágenes, gestos, voces. Barcelona: Paidós, 1986.

La cámara lúcida. Barcelona: Gustavo Gili, 1982.

DELADALLE, G. Leer a Peirce hoy. Barcelona: Gedisa, 1996.

DUBOIS, P. El acto fotográfico. De la Representación a la Recepción. Barcelona: Paidós, 1986.

FARÍAS DE ESTANY, J. e Írida de MOLERO. "La especificidad semiótica del texto fotográfico”, en Revista Opción N 54, 2007.

GÓMEZ, M. La iconología. Un método para reconocer la simbología oculta en las obras de arquitectura. Caracas: Argos, 38, 2003, 7-39. 
Jenny Farías - María Inés Mendoza

NEWTON, H. Private Property. Berlín: Schirmer's Visual Library, 1990.

MANGIERI, R. Las fronteras del texto, Murcia: Universidad de Murcia. Servicio de Publicaciones, 2000.

MERREL, F. Semiótica de C.S. Peirce. Maracaibo: Universidad del Zulia. Colección de semiótica Latinoamericana 1, 1998.

PANOFSKY, Edwin. El significado en las artes visuales. Buenos Aires: Infinito, 1970.

PEIRCE, C. El ícono, el índice y el símbolo. (S. Barrena, Trad.). Disponible en: http://www.unav.es/gep/IconoIndiceSimbolo.html

(consultado : 2007, junio, 21). (Trabajo original 1893-1903), 2005.

- La ciencia de la semiótica. Buenos Aires: Nueva visión, 1986.

VITALE, A. El estudio de los signos. Buenos Aires: Eudeba, 2002.

ZAVALA, L. Elementos del discurso cinematográfico. México: Universidad Autónoma Metropolitana, 2003. 